\title{
Estimated Withdrawals and Use of Water in Connecticut in 1995
}

\section{INTRODUCTION}

Throughout history, water resources in Connecticut have proven useful in many ways - energizing mills of the past, supplying water for drinking, and providing recreational opportunities for all to enjoy. Although Connecticut has abundant water resources, they are not uniformly distributed, and supplies are not always near the centers of demand (Healy, 1990). With continued development, water-use issues and concerns in Connecticut will persist and become increasingly relevant to all citizens.

The U.S. Geological Survey (USGS), in cooperation with the Connecticut Department of Environmental Protection (DEP). has collected and archived water-use information since the late 1970 's as part of the National Water-Use Information Program, which is designed to collect, store, and analyze water-use information on a national level. Every 5 years, water-use estimates from individual states are compiled nationally in a USGS Circular, "Estimated Use of Water in the United States" (Solley and others, 1993) and locally, in publications such as this. This fact sheet presents the estimates of water withdrawals in Connecticut compiled for the 1995 national compilation of water use.

\section{WATER WITHDRAWALS}

Estimates of water withdrawals in this fact sheet are divided into the following categories: public supply, domestic, commercial, industrial and mining, agriculture and irrigation, and thermoelectric power generation. Other categories in the national compilation that are not included in this fact sheet are hydroelectric-power generation, wastewater treatment, and reservoir evaporation. Detailed descriptions of all categories as well as a glossary of wateruse terms are available in the USGS Circular, "Estimated Use of Water in the United States in 1990" (Solley and others, 1993).

Total estimated freshwater withdrawals during 1995 in Connecticut were about 1,275 Mgal/d (million gallons per day). Total withdrawals can be divided into surface-water withdrawals of $1,109 \mathrm{Mgal} / \mathrm{d}$ and ground-water withdrawals of $166 \mathrm{Mgal} / \mathrm{d}$. Freshwater withdrawals during 1995 by category and hydrologic basin are shown in table 1 and on figures 2 and 3. Withdrawals of saline surface water, which is used by thermoelectric plants for cooling, totaled 3,180 Mgal/d; these estimates are not included in the tables or figures.

Freshwater used at thermoelectric plants in Connecticut accounted for 60 percent of total withdrawals of water in the State. This was followed by public supply (3I percent), domestic (4 percent), agriculture and irrigation ( 2 percent), and commercial ( 2 percent). Withdrawals for use in industrial and mining operations accounted for 1 percent of the total withdrawals of water in 1995 (table 1; fig. 2). In 1995, public suppliers in Connecticut withdrew and distributed approximately $393 \mathrm{Mgal} / \mathrm{d}$, of which 16 percent was from ground water. Eight out of 10 people in Connecticut obtain their water from public suppliers (U.S. Department of Commerce, 1991). Distributions made by public suppliers were made to users in the

\section{In 1995, estimated total freshwater withdrawals were 1,275 Mgal/d- $1,109 \mathrm{Mgal} / \mathrm{d}$ from surface-water \& $166 \mathrm{Mgal} / \mathrm{d}$ from ground water}

following categories: domestic

(191 Mgal/d), commercial (89.3 Mgal/d), industrial (41.7 Mgal/d), and thermoelectric $(1.1 \mathrm{Mgal} / \mathrm{d})$. The remainder of the water withdrawn by public-water suppliers (69.9 Mgal/d) represented public water use, losses, and transfers.

Areas of Connecticut with the largest withdrawals during 1995 were the Lower Connecticut and Housatonic River Basins (fig. 3), which accounted for 55 and 24 percent of total water withdrawn, because of large surface-water withdrawals for thermoelectric power and public supply. The Quinnipiac and Saugatuck River Basins each accounted for 6 percent of total withdrawals (fig. 3), primarily due to public supply and domestic withdrawals.

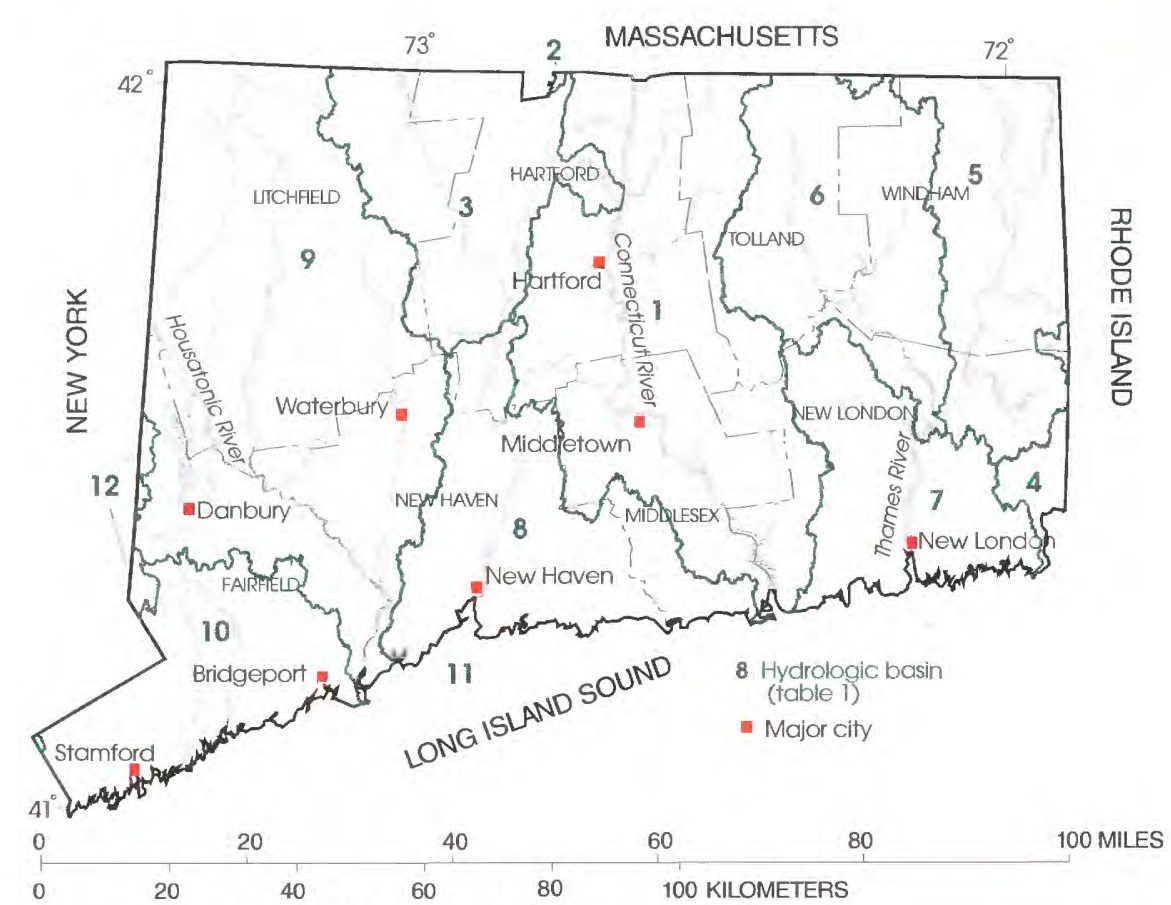

Figure 1. Map of Connecticut, showing hydrologic basins. 
Table 1. Estimated ground-water and surface-water withdrawals in Connecticut in 1995 by water-use category [All values reported in million gallons per day (Mgal/d); GW, ground water; SW, surface water; values are rounded to the nearest $0.01 \mathrm{Mgal} / \mathrm{d}$ or to three significant figures; values may not add to totals because of rounding]

\begin{tabular}{|c|c|c|c|c|c|c|c|c|c|c|c|c|}
\hline \multirow{2}{*}{ Basin } & \multicolumn{2}{|c|}{ Thermoelectric } & \multicolumn{2}{|c|}{ Public supply } & \multicolumn{2}{|c|}{ Domestic } & \multicolumn{2}{|c|}{$\begin{array}{c}\text { Agriculture and } \\
\text { irrigation }\end{array}$} & \multicolumn{2}{|c|}{ Commercial } & \multicolumn{2}{|c|}{$\begin{array}{l}\text { Industrial and } \\
\text { mining }\end{array}$} \\
\hline & GW & SW & GW & SW & GW & SW & GW & SW & GW & SW & GW & SW \\
\hline 1. Lower Connecticut & 0.21 & 613 & 10.7 & 53.0 & 11.3 & 0.00 & 4.89 & 3.57 & 4.51 & 0.30 & 0.76 & 1.68 \\
\hline 2. Westfield & .00 & .00 & .03 & .05 & .01 & .00 & .14 & .11 & .00 & .00 & .00 & .00 \\
\hline 3. Farmington & .00 & .00 & 11.7 & 26.1 & 3.06 & .00 & 3.45 & 2.59 & 2.43 & .92 & .19 & .58 \\
\hline 4. Pawcatuck-Wood & .00 & .00 & .19 & 1.24 & .36 & .00 & .05 & .03 & .11 & .00 & .00 & .06 \\
\hline 5. Quinebaug & .00 & .00 & 1.84 & 4.06 & 3.00 & .00 & .46 & .23 & 3.40 & .00 & .18 & .62 \\
\hline 6. Shetucket & .00 & .00 & 2.08 & 7.23 & 10.1 & .00 & .81 & .45 & 3.30 & .00 & .18 & .71 \\
\hline 7. Thames & .00 & .00 & 1.93 & 12.7 & 2.78 & .00 & .52 & .26 & .86 & .00 & .03 & .49 \\
\hline 8. Quinnipiac & .00 & .00 & 11.4 & 50.2 & 5.65 & .00 & 2.30 & 1.70 & 2.18 & .28 & .49 & .87 \\
\hline 9. Housatonic & .00 & 147 & 15.4 & 118 & 11.4 & .00 & 2.82 & 1.96 & 4.83 & .01 & 1.22 & 1.58 \\
\hline 10. Saugatuck & .00 & .00 & 8.48 & 51.3 & 6.52 & .00 & 1.40 & 1.04 & 3.30 & .00 & .70 & .84 \\
\hline 11. Long Island Sound & .00 & .00 & .00 & .00 & .00 & .00 & .00 & .00 & .00 & .00 & .00 & .00 \\
\hline 12. Lower Hudson & .00 & .00 & .70 & 4.20 & .61 & .00 & .13 & .08 & .27 & .00 & .05 & .08 \\
\hline State total & .21 & 760 & 64.5 & 328 & 54.8 & .00 & 17.0 & 12.0 & 25.2 & 1.51 & 3.81 & 7.52 \\
\hline
\end{tabular}

\section{COMPARISON OF WATER} WITHDRAWALS, 1990 AND 1995

Total freshwater withdrawals were estimated to be $1,070 \mathrm{Mgal} / \mathrm{d}$ in 1990 (Korzendorfer and others, 1995). The 1995 estimate $(1.275 \mathrm{Mgal} / \mathrm{d})$ is 19 percent more than the 1990 estimate. In 1990 and 1995, the largest withdrawals of water were for thermoelectric power, and surface-water withdrawals exceeded ground-water withdrawals. The 19 percent increase in withdrawals results from increases in estimates for the following categories: public supply (374 to $393 \mathrm{Mgal} / \mathrm{d}$ ), domestic (46.3 to $54.8 \mathrm{Mgal} / \mathrm{d}$ ), commercial (18.1 to 26.7 $\mathrm{Mgal} / \mathrm{d}$ ), thermoelectric power (530 to $760 \mathrm{Mgal} / \mathrm{d})$, and agriculture and irrigation (16 to $29 \mathrm{Mgal} / \mathrm{d}$ ). Additional investigation is needed to determine the reasons for these increases, although data availability and methodology differences between the 1990 and 1995 compilations are likely contributing factors.

\section{REFERENCES}

Healy, D.F., 1990, Connecticut water supply and use, with sections on "public-supply water use" by H.D. Sternberg and "water management" by C.J. Hughes, in Carr, J.E., Chase, E.B., Paulson, R.W., and Moody, D.W. (compilers), National Water Summary 1987-Hydrologic events and water supply and use: U.S. Geological Survey WaterSupply Paper 2350, p. 193- 200.

Korzendorfer, B.A., Horn, M.A., and Medalie, Laura, 1995, Estimated withdrawals and use of freshwater in Connecticut, 1990: U.S. Geological Survey Water-Resources Investigations Report 93-4010, 1 p.

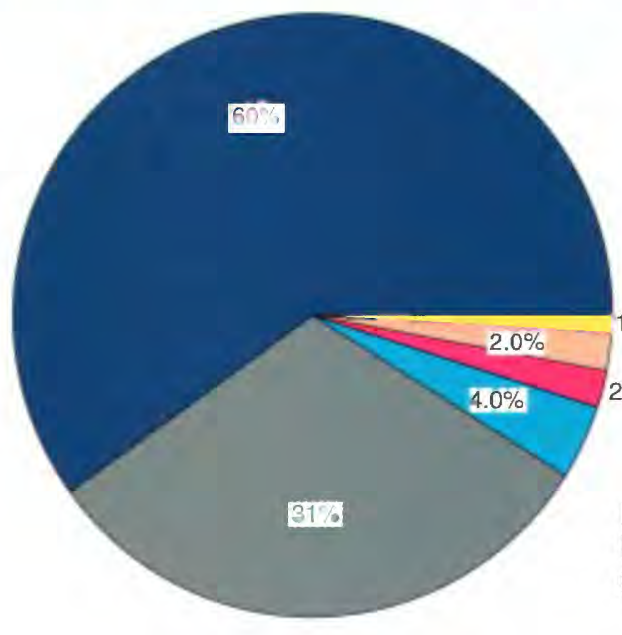

Thermoelectric (760 Mgal/d)

- Public Supply (393 Mgal/d)

Domestic (54.8 Mgal/d)

Agriculture \& Irrigation (29.0 Mgal/d)

Commercial (26.7 Mgal/d)

Industrial \& Mining (11.3 Mgal/d) $1.0 \%$ $2.0 \%$

Figure 2. Freshwater withdrawals by category, 1995 (Mgal/d, million gallons per day)

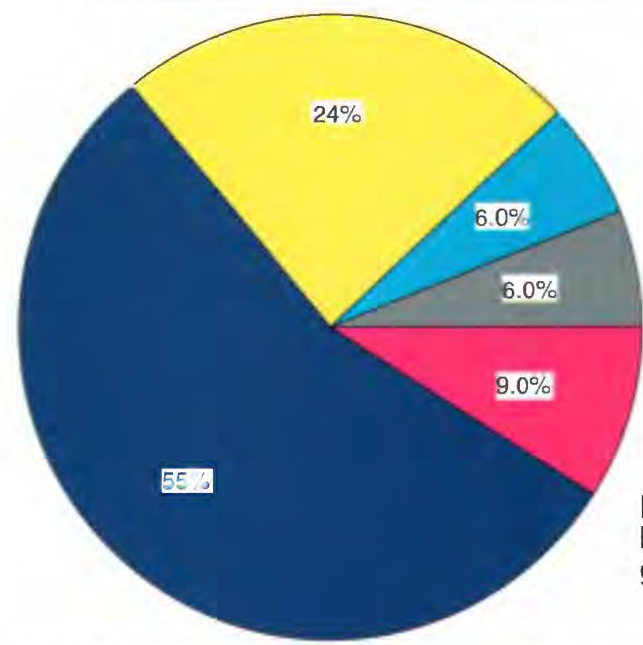

Lower Connecticut (704 Mgal/d)

[1. Housatonic (304 Mgal/d)

- Quinnipiac (75.1 Mgal/d)

- Saugatuck (73.6 Mgal/d)

- All others (118 Mgal/d)

Solley, W.B., Pierce, R.R., and Perlman, H.A., 1993, Estimated use of water in the United States in 1990: U.S. Geological Survey Circular 1081, $76 \mathrm{p}$.

U.S. Department of Commerce, 1991,1990 census of population and housing, summary
Figure 3. Freshwater withdrawals by basin, 1995 (Mgal/d, million gallons per day)

population and housing characteristics, Connecticut: Washington D.C., Census

Bureau, publication 1990/CPH-1-8, 64 p.

- Timothy W. Frick

layout by B.A. Korzendorfer 